\title{
RANCANG BANGUN DAN PENGUJIAN BATTERY PACK LITHIUM ION
}

\author{
Achmad Rais Wiguna ${ }^{1}$, Tohazen ${ }^{2}$, Nuha Nadhiroh ${ }^{3}$, Sri Lestari ${ }^{4}$, Murie Dwiyaniti ${ }^{5}$ \\ Prodi ${ }^{1,2}$ Prodi Teknik Listrik, Jurusan Teknik Elektro, Politeknik Negeri Jakarta \\ Jl Prof.Dr.GA Siwabessy, Kampus Baru UI Depok 16425 \\ 3,5 Prodi Teknik Otomasi Listrik Industri Listrik, Jurusan Teknik Elektro, Politeknik Negeri Jakarta \\ Jl Prof.Dr.GA Siwabessy, Kampus Baru UI Depok 16425 \\ ${ }^{4}$ Prodi Telekomunikasi, Jurusan Teknik Elektro, Politeknik Negeri Jakarta \\ Jl Prof.Dr.GA Siwabessy, Kampus Baru UI Depok 16425
}

e-mail: ${ }^{1}$ achmad.raiswiguna.te18@mhsw.pnj.ac.id, ${ }^{5}$ murie.dwiyaniti@elektro.pnj.ac.id

\begin{abstract}
Some rural areas in Indonesia still have low electrification ratios because of the geographical location built into the electricity grid. An alternative solution to get electrical energy is to use solar panels. However, the output from solar panels is intermittent, so it requires a storage area for electrical energy or batteries. The latest battery technology is lithium-ion batteries, which have a long service life and are easy to maintain. However, currently, the voltage generated by the lithium-ion battery is only 3.7V, while if you want to use it as a home power source, a minimum voltage of 12 Volts is required. So the researchers designed a lithium-ion battery that produces a voltage of $12 \mathrm{~V}$ by assembling the batteries in series and parallel, arranged in a compact panel and equipped with a battery management system (BMS). The performance of this battery is tested from the unity of the battery to the realization of the battery pack. The test results, the battery pack produces a voltage of $12 \mathrm{~V}, 60 \mathrm{Ah}$, and can be used for 8 hours for a load of $57 \mathrm{~W}$. The time required to charge the battery is 24 hours with a 2 A charger.
\end{abstract}

Keywords: battery pack, lithium-ion, electrification ratio, solar panels.

\begin{abstract}
ABSTRAK
Beberapa daerah pedesaan di Indonesia masih memiliki rasio elektrifikasi yang rendah karena letak geografis yang menyulitkan dalam membangun jaringan listrik. Alternatif solusi agar mendapatkan energi listrik adalah menggunakan panel surya. Namun, keluaran dari panel surya bersifat intermitten, sehingga memerlukan tempat penyimpanan energi listrik atau baterai. Teknologi baterai terkini adalah baterai lithium ion yang diklaim memiliki lifetime yang lama dan mudah dalam perawatan. Namun saat ini, tegangan yang dihasilkan oleh baterai lithium ion hanya 3,7V sedangkan jika ingin dimanfaatkan sebagai sumber listrik rumah tangga diperlukan tegangan minimal 12 Volt. Sehingga peneliti mendesain baterai lithium ion yang menghasilkan tegangan $12 \mathrm{~V}$ dengan cara merangkai baterai secara seri dan parallel, serta disusun dalam panel yang compact dan dilengkapi dengan baterai managemen system (BMS). Kinerja dari baterai ini diuji mulai persatuan baterai hingga terwujudnya baterai pack. Hasil pengujian, baterai pack menghasilkan tegangan $12 \mathrm{~V}, 60 \mathrm{Ah}$, dan dapat digunakan selama 8 jam untuk beban $57 \mathrm{~W}$. Waktu yang dibutuhkan untuk pengisian baterai yaitu 24 jam dengan pengisi daya $2 \mathrm{~A}$.
\end{abstract}

Kata kunci: baterai pack, lithium ion, rasio elektrifikasi, panel surya. 


\section{PENDAHULUAN}

Beberapa daerah pedesaan di Indonesia masih memiliki rasio elektrifikasi yang rendah. Salah satu masalah utamanya adalah letak geografis yang mengakibatkan sulitnya membangun jaringan listrik. Di beberapa daerah, pembangkit listrik tenaga diesel telah dibangun untuk memasok listrik. Namun, hal ini menimbulkan masalah lain dalam pengangkutan sumber energi primer ke wilayah sasaran yang akan meningkatkan biaya penyediaan listrik [1].

Salah satu teknologi yang banyak dikembangkan saat ini untuk mengatasi hal tersebut adalah pemanfaatan baterai. Baterai adalah media tempat penyimpanan energi listrik dalam bentuk energi kimia yang dapat dikonversikan menjadi energi listrik. Saat ini, sangat banyak macam bentuk baterai dan jenisnya. Penggunaannya tergantung pada kebutuhan daya, arus dan tegangan yang di perlukan oleh masing-masing peralatan elektronik. Baterai dapat dimanfaatkan untuk menyimpan energi listrik yang dihasilkan dari potensi sumber energi terbarukan seperti biomassa, hidro, angin, dan matahari [1], [2].

Baterai merupakan sebuah sel listrik dimana didalamnya berlangsung proses elektrokimia yang reversible (dapat berkebalikan) dengan efisiensi yang tinggi [3]. Baterai berbasis lithium memiliki kelebihan dibanding baterai konvensional seperti Nickel-Cadmium, NickelMetalhydrate ataupun Lead Acid[4]-[6].

Baterai lithium-ion menjadi pilihan tepat untuk alat ini karena memiliki kelebihan yaitu density energi yang tinggi, density daya yang tinggi, self discharge yang rendah, fast charging, tidak ada efek memori, dan siklus hidup yang lama[7]-[10]. Namun, baterai berbasis lithium juga memiliki kekurangan yaitu sangat sensitif terhadap temperatur. Saat ini, tegangan yang dihasilkan oleh baterai lithium ion hanya $3,7 \mathrm{~V}$ sedangkan jika ingin dimanfaatkan sebagai sumber listrik rumah tangga diperlukan tegangan minimal 12 Volt.

Sehubungan dengan hal tersebut, artikel ini mengusulkan rancang Bangun Battery Pack sebagai solusi untuk menyediakan listrik ke daerah pedesaan. Dimana alat ini terdiri atas baterai lithium-ion yang dirangkai seri dan parallel yang terhubung dengan battery management system (BMS), serta dibungkus oleh sebuah casing (baterai pack) berbahan PVC, selain itu, terdapat kipas pada sisi kanan dan kiri untuk meredam panas pada casing/panel. Untuk memudahkan memantau parameter kelistrikan baterai, LCD dipasang pada pintu depan panel.

\section{METODE PENELITIAN}

Metode penelitian yang digunakan adalah metode rancang bagun atau experiment. Tahapan penelitian terdiri dari:

1. Desain baterai pack

2. Membuat baterai pack

3. Menguji kinerja baterai pack

Baterai lithium ion yang digunakan adalah baterai 18650, dengan tegangan 3,7 Volt dan kapasitas yeng bervariasi yaitu, $1500 \mathrm{mAh}, 2000$ mAh, dan $3000 \mathrm{mAh}$.

Setiap cell baterai li-ion dirangkai secara seri dan parallel seperti yang ditunjukkan pada Gambar 1 hingga menghasilkan tegangan $12 \mathrm{~V}$ dan kapasitas 20 Ah. Setiap baterai pack dilengkapi dengan BMS seperti gambar 2 .

Side A

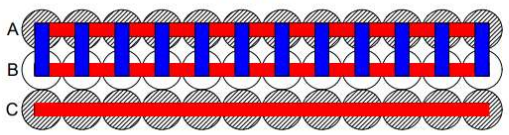

Side B

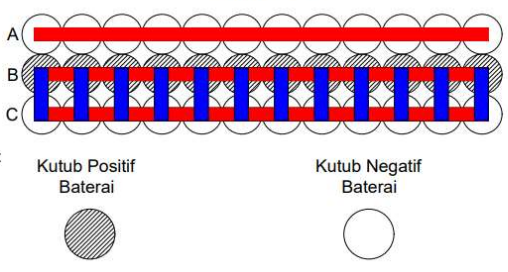

Gambar 1. Rangkaian baterai pack 


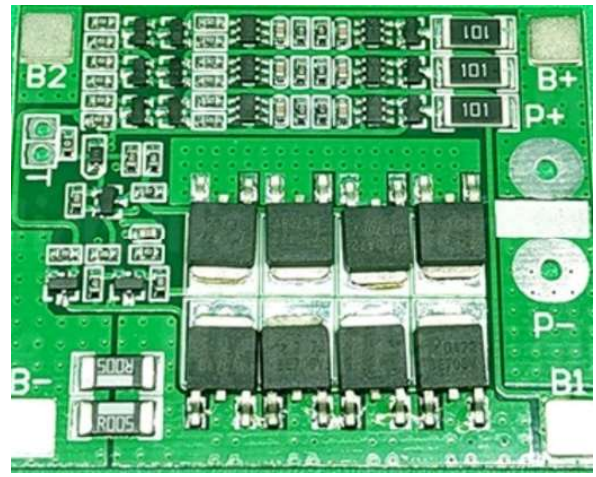

Gambar 2. BMS

Langkah - langkah penelitian yang dilakukan adalah :

1. Membuat rancangan battery pack.

2. Membangun hasil rancangan battery pack.

3. Membuat perhitungan kapasitas battery pack.

4. Pengambilan data pengukuran tegangan dan arus battery pack dan keseluruhan dengan cara menghubungkan beban AC atau DC dan merekam data tegangan dan arus yang diperlukan sampai kondisi baterai lemah.

5. Pengambilan data pengukuran tegangan dan arus battery pack dengan cara menghubungkan alat pengisi daya dan merekam data tegangan dan arus yang diperlukan hingga baterai terisi penuh

6. Analisa data hasil pengukuran.

\section{HASIL DAN PEMBAHASAN}

a. Rancangan Battery Pack

Perancangan dibuat dengan aplikasi AutoCad. Hasilnya berupa rancangan 3D bentuk alat yang dapat dilihat pada Gambar 3 dan diagram pengawatan alat yang dapat dilihat pada Gambar 4.
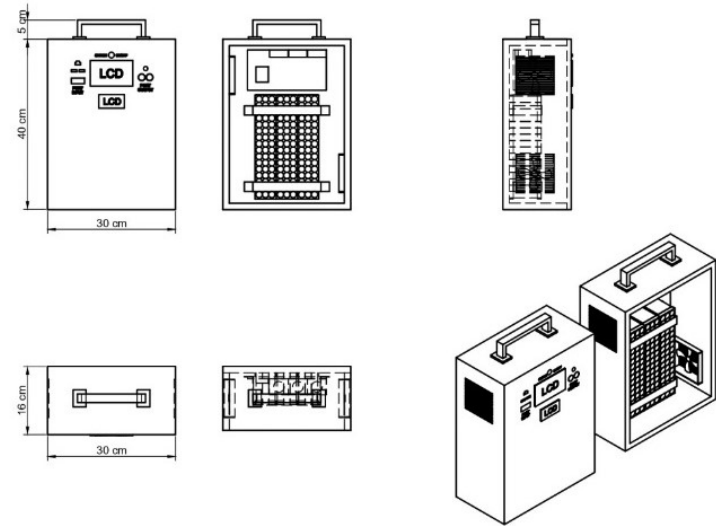

Gambar 3. Rancangan 3D Battery Pack

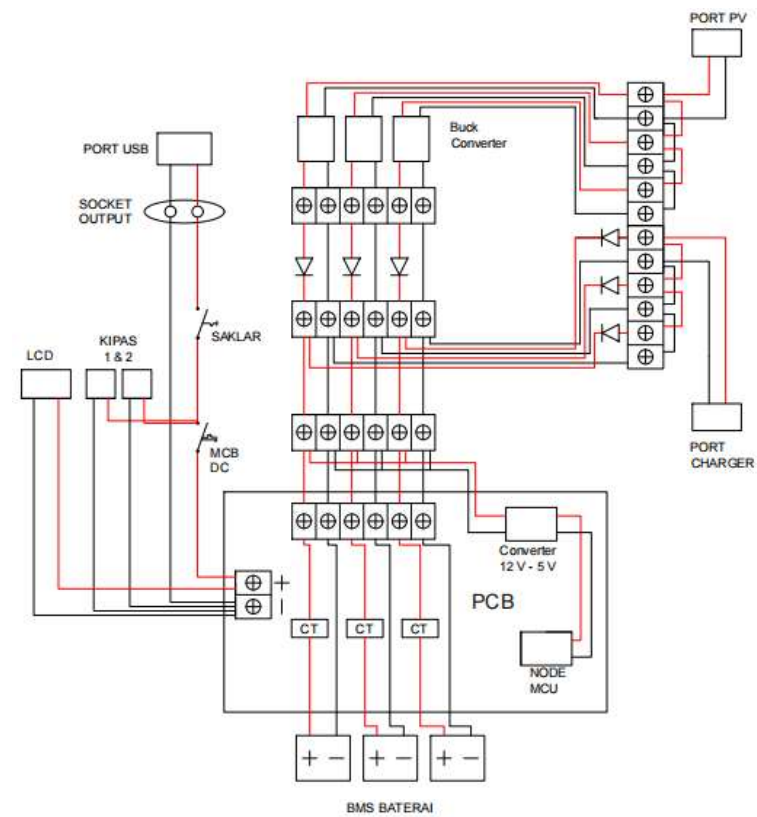

Gambar 4. Diagram Pengawatan

\section{b. Model Battery Pack}

Dari hasil perancangan dibuatlah realisasi alat yang dapat dilihat pada Gambar 5. Panel yang digunakan berbahan besi serta terdapat layar LCD dan terminal input maupun output baterai yang ada pada pintu panel.

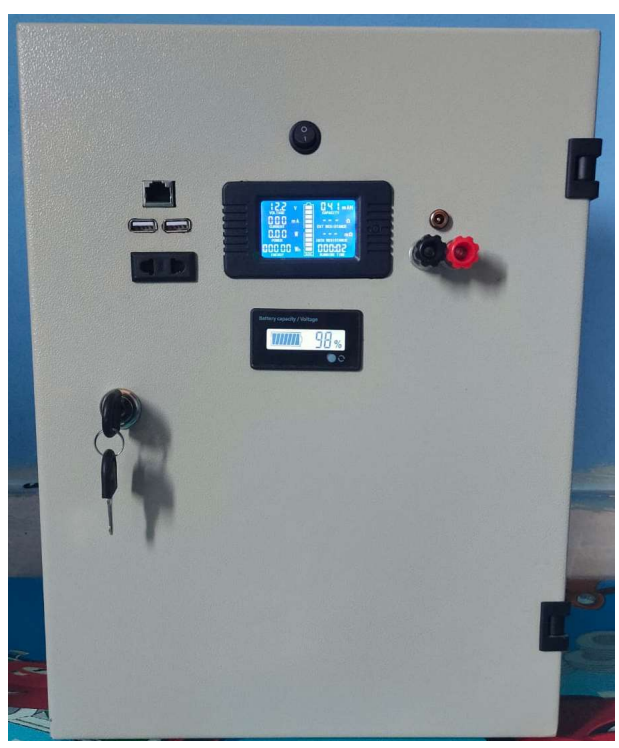

Gambar 5. Realisasi Alat

\section{c. Perhitungan Kapasitas Battery Pack}

Baterai pack lithium ion dirangkai secara seri dan parallel agar menghasikan kapasitas $60 \mathrm{Ah}, 12$ Volt. Susunan baterai pack dapat dilihat pada Gambar 6. 


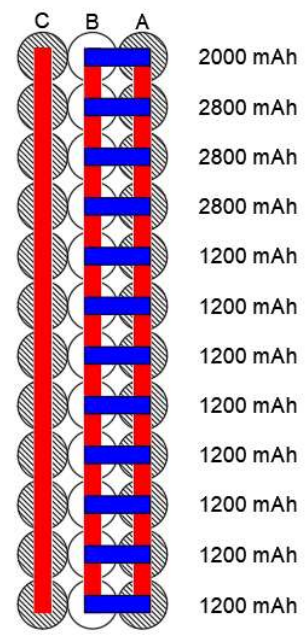

Gambar 6. Diagram Kapasitas Battery Pack

Berdasarkan Gambar 6 maka kapasitas setiap baterai pack yaitu :

$$
\begin{aligned}
\text { Kapasitas }= & (1200 \mathrm{mAh} \times 8)+(2800 \mathrm{mAh} \times 3) \\
& +2000 \mathrm{mAh} \\
= & 9600 \mathrm{mAh}+8400 \mathrm{mAh}+2000 \\
= & 20.000 \mathrm{mAh} \\
= & 20 \mathrm{Ah} \times 3 \text { pack }=60 \mathrm{Ah} \\
\text { Energi } \quad & =60 \mathrm{Ah} \times 12 \mathrm{~V}=720 \mathrm{Wh}
\end{aligned}
$$

\section{d. Data Pengukuran Discharge}

Hasil pengukuran kinerja battery pack pada saat pengisian dan pengosongan didapat dengan menghubungkan beban AC atau DC. Nilai parameter tegangan, arus dan daya baterai dapat dilihat pada Gambar 7 - 10.

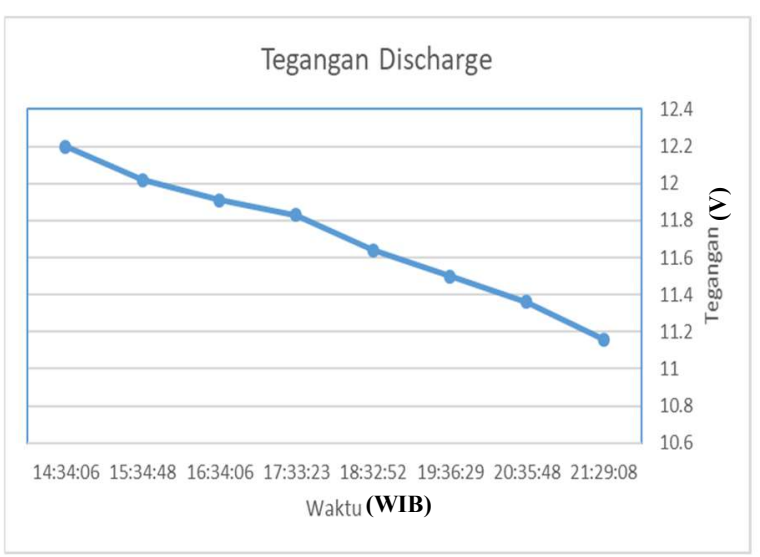

Gambar 7. Grafik Tegangan Discharge Beban $\mathrm{AC}$

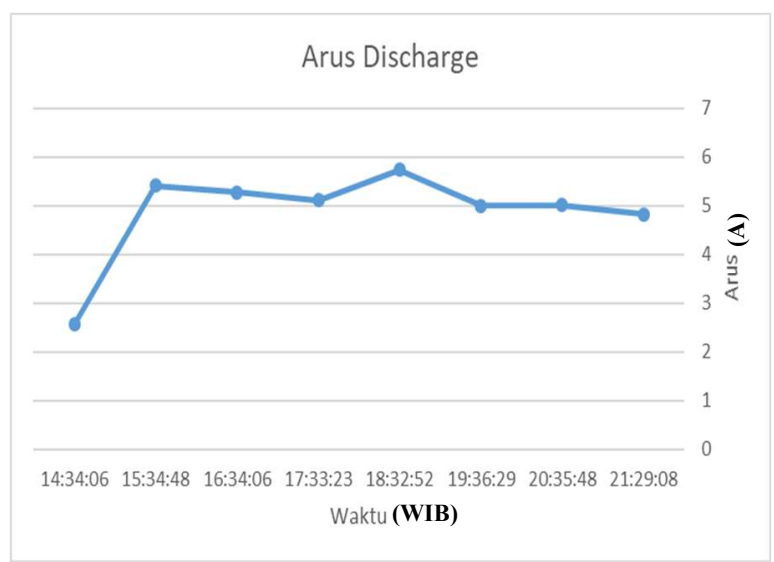

Gambar 8. Grafik Arus Discharge Beban AC

Untuk pengujian discharge berlangsung selama 7 jam dengan beban AC (57 W). Lamanya pengujian tergantung kepada besarnya daya beban yang dipasang, semakin besar daya beban yang dipasang maka semakin cepat waktu pengujian/pemakaian. Pada Gambar 7 terlihat bahwa tegangan baterai pack terus turun seiring dengan waktu pemakaian. Dalam waktu 7 jam tegangan turun sebesar 1 Volt. Idealnya, tegangan baterai tidak boleh turun harus tetap pada tegangan 12 Volt. Namun karena adanya degredasi atau hambatan dalam pada baterai pack lithium ion menyebabkan drop tegangan. Jika kondisi drop tegangan sering terjadi maka lifetime baterai akan pendek.

Sedangkan pada Gambar 8 terlihat nilai arus yang membuktikan bahwa battery pack dapat bekerja memberikan energi listrik pada beban.

Pengujian ini dilakukan hingga indikator kapasitas baterai pada LCD pintu panel menunjukan 20\%. Arus pada baterai juga cenderung stabil, pada waktu 14:34:06 - 15:34:48 terjadi kenaikan arus yang cukup tinggi hal ini dapat disebabkan pada waktu 14:34:06 saat arus masih starting, sensor sudah membaca dan mengirim data.

Pengujian discharge selanjutnya adalah menggunakan beban DC. Hasil pengujian terlihat pada Gambar 9 dan 10. 


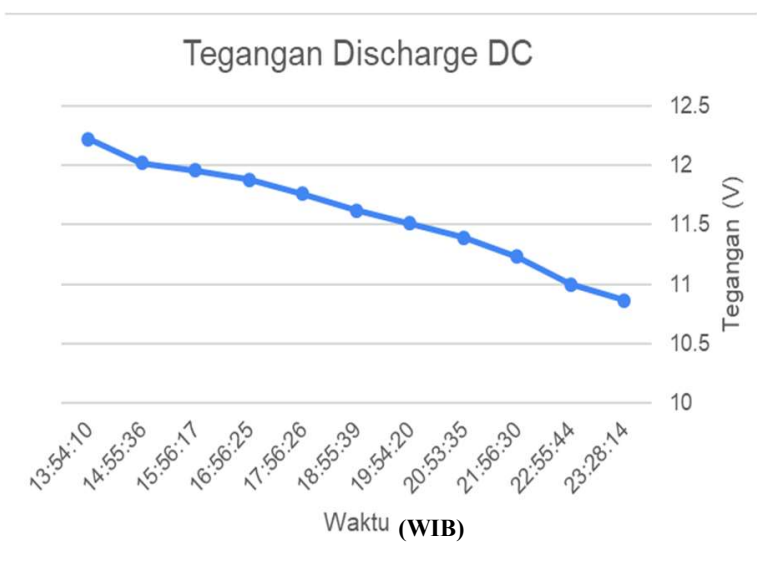

Gambar 9. Grafik Tegangan Discharge Beban

DC

\section{Arus Discharge Beban DC}

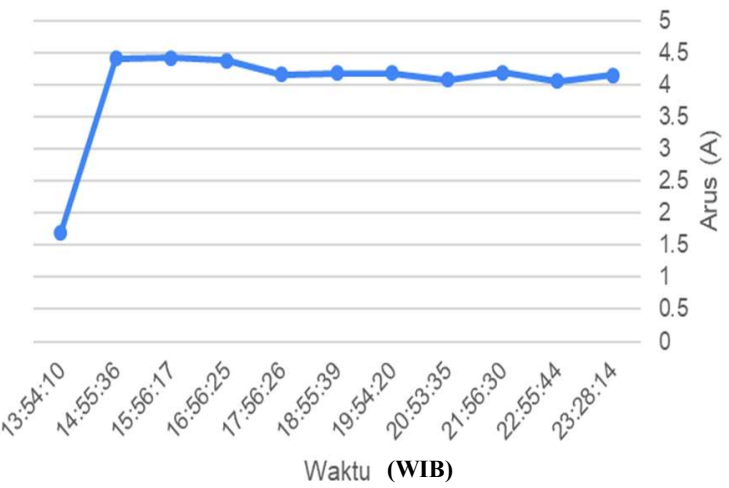

Gambar 10. Grafik Arus Discharge Beban DC

Untuk pengujian discharge berlangsung selama 10 jam dengan beban DC $(50 \mathrm{~W})$. Lamanya pengujian tergantung kepada besarnya daya beban yang dipasang, semakin besar daya beban yang dipasang maka semakin cepat waktu pengujian/pemakaian.

Arus pada baterai juga cenderung stabil, pada waktu 13:54:10 - 14:55:36 terjadi kenaikan arus yang cukup tinggi hal ini dapat disebabkan pada waktu 13:54:10 saat arus masih starting, tetapi sensor sudah membaca dan mengirim data. Pengujian ini dilakukan hingga indikator kapasitas baterai pada pintu panel menunjukan $15 \%$.

\section{e. Data Pengukuran Charge}

Hasil pengukuran baterai pack didapat dengan menghubungkan alat pengisi daya atau powersupply sebagai pengisi daya. Nilai parameter tegangan, arus dan daya baterai dapat dilihat pada Gambar 11-14.

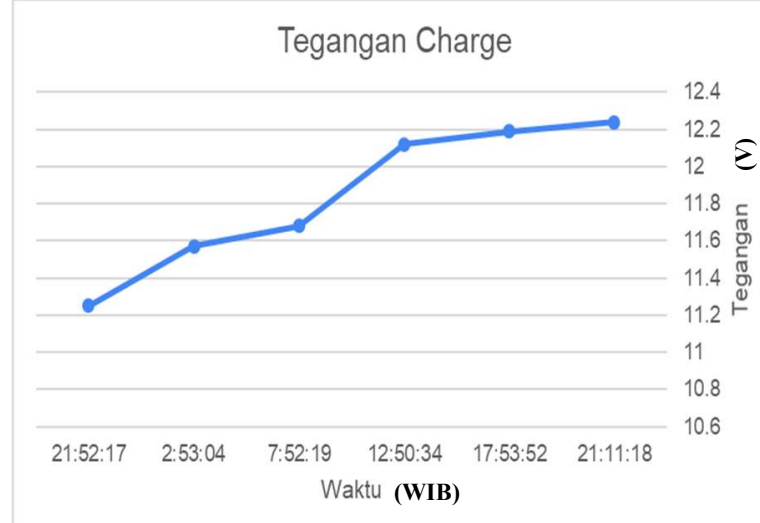

Gambar 11. Grafik Tegangan Charge Beban AC

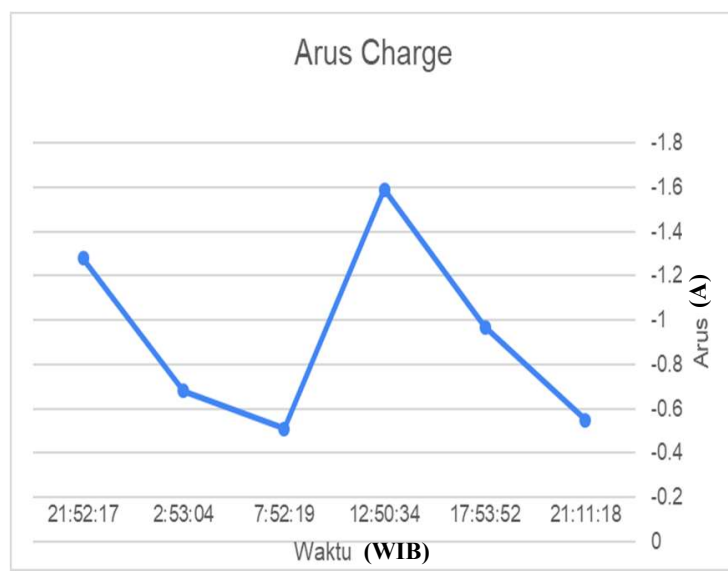

Gambar 12. Grafik Arus Charge Beban AC

Untuk pengisian jam 21:52 digunakan adaptor $12 \mathrm{~V}$; $2 \mathrm{~A}$ tanda (-) pada data arus menunjukkan bahwa arus mengarah ke baterai yang berarti pengisian sedang berlangsung. Lamanya pengisian tergantung kepada besarnya arus yang mengalir ke baterai, semakin besar maka pengisian semakin cepat. Namun, setiap baterai memiliki batas maksimal arus pengisian dan juga semakin besar arus maka suhu juga akan ikut naik. Karena arus yang terlalu kecil maka pada jam 08:58 digunakan power supply $12 \mathrm{~V} ; 10$ A sebagai alat pengisi baterai agar waktu yang pengisian menjadi lebih cepat, maka dari itu saat waktu 7:52:19 - 12:50:34 terjadi kenaikan arus yang signifikan.

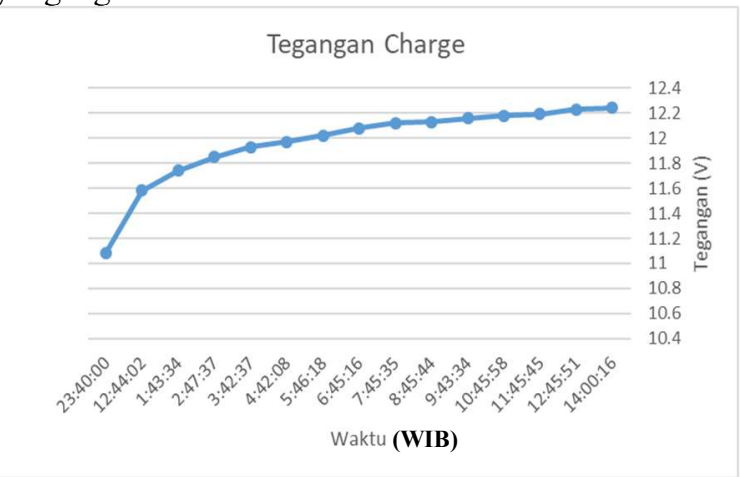




\section{Rancang Bangun dan Pengujian Battery Pack Lithium}

Gambar 13. Grafik Tegangan Charge Beban DC

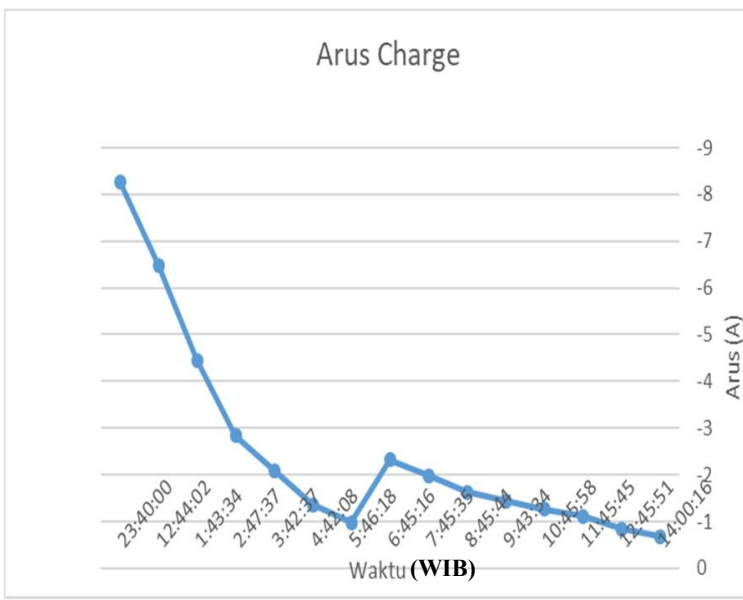

Gambar 14. Grafik Arus Charge Beban DC

Untuk pengisian digunakan powersupply 12 V; 10A tanda (-) pada data arus menunjukkan bahwa arus mengarah ke baterai yang berarti pengisian sedang berlangsung. Lamanya pengisian tergantung kepada besarnya arus yang mengalir ke baterai, semakin besar maka pengisian semakin cepat. Namun, setiap baterai memiliki batas maksimal arus pengisian dan juga semakin besar arus maka suhu juga akan ikut naik. Waktu pengisian memakan waktu \pm 12 jam. Penggunaan alat pengisi daya lebih cepat dengan menggunakan powersupply dan ini dapat membuktikan bahwa nilai arus berpengaruh terhadap lama pengisian battery pack. Pada waktu 5:46:18 terjadi kenaikan arus, hal ini disebabkan karena pengaturan nilai tegangan pada powersupply diubah yang berdampak kepada nilai arus.

\section{KESIMPULAN}

Baterai pack telah berhasil dibuat dan berfungsi dengan baik. Lama pemakaian baterai tergantung pada beban yang digunakan, semakin besar daya yang digunakan maka kapasitas baterai akan semakin cepat habis. Baterai pack yang dibuat pada penelitian ini dapat bertahan selama 8 jam dengan beban $57 \mathrm{~W}$. Untuk waktu pengisian baterai tergantung pada besarnya arus yang mengalir ke baterai, semakin besar arus yang mengalir ke baterai maka waktu pengisian akan semakin cepat. Namun, setiap baterai memiliki batas maksimal arus pengisian.

\section{Ucapan Terima Kasih}

Terima kasih kepada UP2M dan PPTV Prodi Teknik Otomasi Listrik Industri, Politeknik Negeri Jakarta yang telah mendanai kegiatan penelitian ini.

\section{DAFTAR PUSTAKA}

[1] A. Dwi Riana et al., "Implementation of talis and dc house system for rural areas in Indonesia," MATEC Web Conf., vol. 218, pp. 1-7, 2018, doi: 10.1051/matecconf/201821801006.

[2] A. Pangkung, "Analisis Penggunaan Baterai Lithium Sebagai Pengganti Aki ( Accu ) Pada Pembangkit Listrik Tenaga Surya," vol. 2017, pp. 116-121, 2017.

[3] M. Thowil Afif and I. Ayu Putri Pratiwi, "Analisis Perbandingan Baterai LithiumIon, Lithium-Polymer, Lead Acid dan Nickel-Metal Hydride pada Penggunaan Mobil Listrik - Review," J. Rekayasa Mesin, vol. 6, no. 2, pp. 95-99, 2015, doi: 10.21776/ub.jrm.2015.006.02.1.

[4] M. Otong, "Perancangan Modular Baterai Lithium Ion (Li-Ion) untuk Beban Lampu LED," Setrum Sist. Kendali-Tenagaelektronika-telekomunikasi-komputer, vol. 8, no. 2, p. 260, 2019, doi: 10.36055/setrum.v8i2.6808.

[5] Afif, Muhammad Thowil, and Ilham Ayu Putri Pratiwi. " Analisis perbandingan baterai lithium-ion, lithium-polymer, lead acid dan nickel-metal hydride pada penggunaan mobil listrik-review." Jurnal Rekayasa Mesin 6.2 (2015): 95-99.

[6] Akbar, Muhammad, Heri Suyanto, and Hendrianto Husada. Perbandingan Karakteristik Baterai Valve Regulated Lead Acid Dengan Baterai Lithium Pada Modul Photovoltaic Jenis Polycristaline Dengan Modified Coloumb Counting Method. Diss. INSTITUT TEKNOLOGI PLN, 2020.

[7] T. P. Cahyono, T. Hardianto, and B. S. Kaloko, "Pengujian Karakteristik Baterai Lithium-Ion Dengan Metode Fuzzy dengan Beban Bervariasi," J. Arus Elektro ..., 2020, [Online]. Available: https://jurnal.unej.ac.id/index.php/E-

JAEI/article/view/19708.

[8] I. Susanti, R. Rumiasih, C. RS, and A. Firmansyah, "Pengisiannya Pada Mobil Listrik," Elektra, vol. 4, no. 2, pp. 29-37, 2019.

[9] M. Oswal, J. Paul, and R. Zhao, "A Comparative Study of Lithium-Ion Batteries.," Univ. South. Calif., p. 31, 2010, [Online]. Available: http://wwwscf.usc.edu/ rzhao/LFP_study.pdf.

[10] X. Zeng et al., "Commercialization of Lithium Battery Technologies for Electric Vehicles," Adv. Energy Mater., vol. 9, no. 27, 2019, doi: 10.1002/aenm.201900161. 